DOI: $10.6060 / \mathrm{mhc} 140508 \mathrm{~b}$

\title{
(24-Crown-8)-Linked Dimeric Phthalocyanines and Their Metal Complexes
}

\author{
Kirill P. Birin, ${ }^{a}$ Victor N. Chugunov, ${ }^{\mathrm{b}}$ Anna A. Krapivenko, ${ }^{\mathrm{b}}$ Yulia G. Gorbunova, ${ }^{\mathrm{a}, \mathrm{c}}$ \\ and Aslan Yu. Tsivadze ${ }^{a, c}$
}

Dedicated to Corresponding member of Russian Academy of Sciences, Prof. O. I. Koifman on the occasion of his Anniversary

\begin{abstract}
${ }^{a}$ A.N. Frumkin Institute of Physical Chemistry and Electrochemistry RAS, 119071 Moscow, Russia
${ }^{\mathrm{b}}$ High Chemical College of Russian Academy of Sciences, 125047 Moscow, Russia

${ }^{\mathrm{c}}$ N.S. Kurnakov Institute of General and Inorganic Chemistry RAS, 119991 Moscow, Russia

${ }^{\circledR}$ Corresponding author E-mail: kirill.birin@gmail.com
\end{abstract}

\begin{abstract}
A convenient synthetic approach towards alkyloxy substituted (24-crown-8)-linked dimeric phthalocyanines is developed. The influence of the alteration of the reaction conditions and the origin of the precursors onto the yield of the target compounds is revealed. The Mg-templated statistical condensation of the mixture of phthalonitriles is found to be the most efficient and versatile pathway. The developed demetallation procedure of obtained Mg-phthalocyanines allows to prepare metal-free (24-crown-8)-linked dimeric phthalocyanines, which are versatile precursors for preparation of other metal complexes. The preliminary AM1 semi-empirical calculations have demonstrated that the dimeric linked phthalocyanine metal complexes may become convenient receptors for recognition of ditopic guests.
\end{abstract}

Keywords: Dimeric phthalocyanine, metal phthalocyanines, statistical condensation, crown ether.

\section{Аимерные фтахоцианины, связанные фрагментом 24-краун-8, и их металлокомплексы}

\author{
К. П. Бирин, ${ }^{a} @$ В. Н. Чугунов, ${ }^{\mathrm{b}}$ А. А. Крапивенко, ${ }^{\mathrm{b}}$ Ю. Г. Горбунова, ${ }^{\mathrm{a}, \mathrm{c}}$ \\ А. Ю. Цивадзе
}

Посвящается Член-корреспонденту РАН профессору О. И. Койфману по случаю его юбилея

${ }^{\mathrm{a}}$ ФБУН Институт физической химии и электрохимии им. А.Н. Фрумкина РАН, 119071 Москва, Россия

${ }^{\mathrm{b}}$ Высший химический колледж РАН, 125047 Москва, Россия

' ФГБУН Институт общей и неорганической химии им. Н.С. Курнакова РАН, 119991 Москва, Россия

@E-mail: kirill.birin@gmail.com

\begin{abstract}
Разработан удобнылй подход к синтезу алкилокси-замещенных димерных фтталочуианинов, связанных фрагментом 24-краун-8. Выявлено влияние условий реакции и природы исходных соединений на выход целевых макроциклов. Показано, что темплатная конденсаџия смеси фталонитрилов в присутствии катионов магния является наиболее эффективным методом синтеза. Разработан эффективньй метод деметаллирования димерных фталоциианиатов магния, позволяющий получать соответствующие свободные фталоциининьл - удобные предшественники в дальнейшем синтезе металлокомплексов. Предварительные полуэмпирические расчеты методом АMI продемонстрировали возможную применимость металлокомплексов полученных димерных фталоцианинов в качестве рецепторов для молекулярного распознавания дитопных молекул.
\end{abstract}

Ключевые слова: Димерный фталоцианин, фталоцианинаты металлов, статистическая конденсация, краунэфиры. 


\section{Introduction}

Development of functional materials in modern chemistry deals with polytopic multicentered receptors. ${ }^{[1-6]}$ Tetrapyrrolic macrocycles, such as porphyrins and phthalocyanines, attract interest in this area as promising compounds with unique chemical, coordination, optical, photophysical and other physico-chemical properties. ${ }^{[7-14]}$ The stability of metal complexes with these classes of ligands allows to mention them as promising molecules for the development of novel homogeneous catalysts $^{[15-19]}$ as well as efficient receptors and sensors. ${ }^{[20-35]}$

The dimeric phthalocyanines, linked by rigid or labile linker are in the scope of modern research.$^{[8,10]}$ The origin of the linker, its geometry and rigidity allows development of ditopic molecules with particular arrangement of phthalocyanine fragments - linear, angular or cofacial. Various molecular fragments were used as linkers in these types of compounds. Thus, substituted aromatic moieties, ${ }^{[10,24,36]}$ ethyleneglycol and thia-ethyleneglycol, ${ }^{[37]}$ ferrocene, ${ }^{[38]}$ metal cation, ${ }^{[39]}$ acetylene, ${ }^{[40]}$ calixarenes, ${ }^{[11,42]}$ alkyl chain, ${ }^{[12]}$ annulated arenes ${ }^{[9,43-45]}$ were applied as spacers.

Crown ethers are of particular interest in this respect, since they present conformationally labile spacer, which configuration can be altered upon chemical impact, i.e. coordination of alkali or ammonium cations. While crown ether substituted phthalocyanines have attracted much interest in past decades, ${ }^{[46,47]}$ the crown ether linked dimeric phthalocyanines provide the completely different type of receptors. In this case the preparation of complexes of metals with coordination difficiency provides access to multicentered pincer-type binding site for electron donating molecules or molecular fragments, while the crown-ether acts only as conformationally labile linker.

Several papers were published, dealing with crown or thiacrown ether linked phthalocyanines. They are partly devoted to crown ether linked phthalocyanine polymers, ${ }^{[14,48-}$ ${ }^{50]}$ while other describe the preparation of discrete ditopic crown ether linked phthalocyanines. ${ }^{[13,51-53]}$ The application of polymeric phthalocyanine networks linked by crown ethers is complicated by the low solubility of the products of the reaction, the irregularity and varied number of linked phthalocyanine fragments. The mentioned peculiarities result in difficulties of physico-chemical characterization of the products, the broadening of the UV-Vis spectra and inapplicability of mass-spectrometry. Moreover, all the published data report low yields not exceeding $10 \%$ for the dimeric crown-ether linked phthalocyanines, either in template-free ${ }^{[53]}$ or Zn-templated ${ }^{[13]}$ mixed condensation of phthalonitriles. Moreover, further separation of the mixture of closely related products is required.

Considering all the mentioned peculiarities of the dimeric phthalocyanines, in present work we focused on the development of the efficient selective synthetic approach for the preparation of crown ether linked dimeric phthalocyanines with 24-crown-8 spacer. The influence of various factors onto the yield and selectivity of the reaction is revealed. The structures and designations of the target compounds are shown in Chart 1.

\section{Experimental}

Isoamyl alcohol (SAFC, $>98 \%$ ) was distilled with sodium prior to use. $\mathrm{CHCl}_{3}$ (reagent grade), 1,2-dichlorobenzene (DCB, Merck, $99 \%$ ), triethylamine(Fluka, $98 \%$ ), 1,8-diazabicyclo-[5.4.0]undec-7-ene (Sigma-Aldrich, $>97.5 \%$ ) and dimethylaminoethanol (Merck, 99\%) were distilled over $\mathrm{CaH}_{2}$. Methanol (Merck, $99.8 \%$ ), glacial acetic acid (reagent grade), trifluoroacetic acid (Sigma-Aldrich, $99 \%$ ), chlorobenzene (Sigma-Aldrich, >99.5\%), dimethylformamide (Sigma-Aldrich, $>99 \%$ ), dimethylacetamide (Sigma-Aldrich, >99.5\%), morpholine (Sigma-Aldrich, >99\%), $\mathrm{Mg}(\mathrm{OAc})_{2}$ (reagent grade) and magnesium filings (reagent grade) were used without further purfication. 3,4,3',4'-Tetracyanodibenzo(24-crown-8) (1), ${ }^{[5]}$ 3,4-dibutoxyphthalonitrile (2) ${ }^{[5]}$ and 3,4-(2ethoxyethoxy)-phthalonitrile (3) ${ }^{[54]}$ were synthesized according to published procedures.

Chromatographic purification was performed at silica (Macherey-Nagel, Silica 60, 0.063-0.2 mm) and neutral alumina (Merck, 0.063-0.2 mm). Size exclusion chromatography was performed at Bio-Beads SX-1 sorbent with $\mathrm{CHCl}_{3} / \mathrm{MeOH}(2.5$ vol. $\%$ of $\mathrm{MeOH})$.

MALDI-TOF mass spectra were recorded at Ultraflex spectrometer (Bruker Daltonics) in positive ion mode with 2,5dihydroxybenzoic acid as matrix. UV-Vis spectra were recorded in $250-900 \mathrm{~nm}$ range at Unicam UV-4 spectrophotometer in rectangular quartz cells with $10 \mathrm{~mm}$ optical path length.

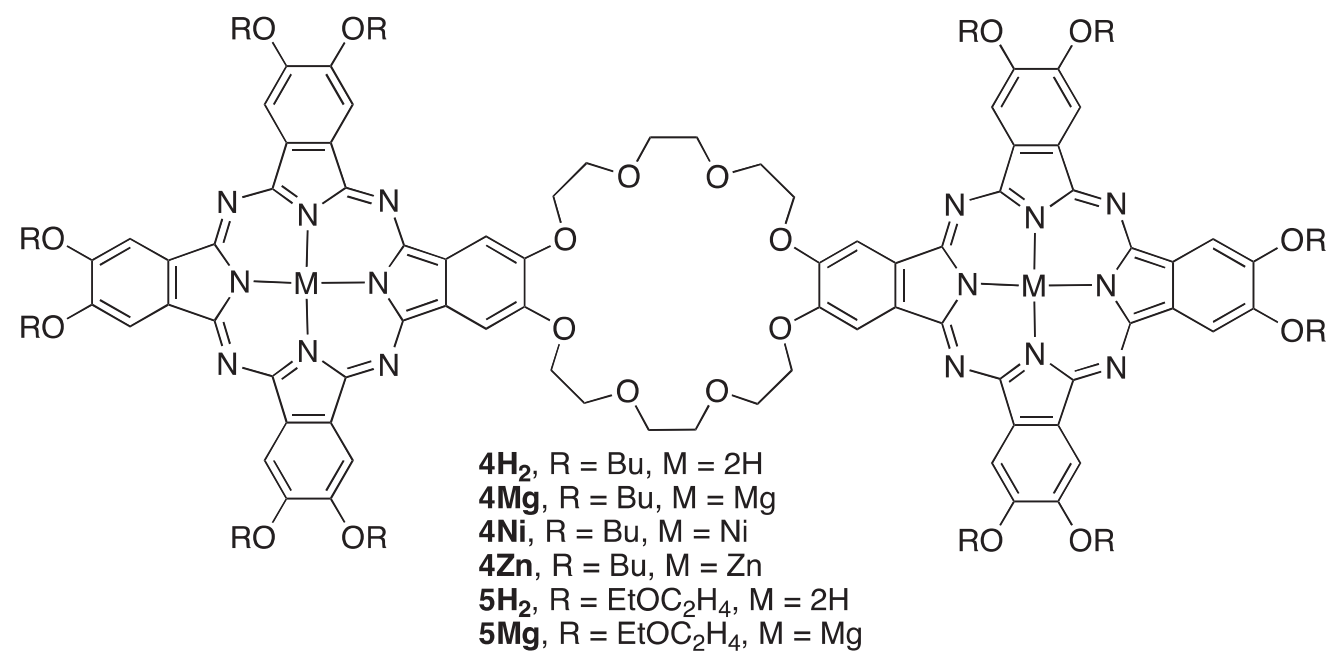

Chart 1. The structures of target dimeric crown-linked phthalocyanines. 
Synthesis of $\mathbf{4 M g}$ and $\mathbf{5 M g}$ with application of $\mathrm{Mg}$ alkoxide. Magnesium filings (21 mg, $0.88 \mathrm{mmol}$ ) were dissolved in isoamyl alcohol $(4 \mathrm{ml})$ in the presence of catalytical amount of $\mathrm{I}_{2}$ in argon atmosphere at $170{ }^{\circ} \mathrm{C}$. The heating was maintained until of $\mathrm{Mg}$ was completely consumed ( $c a .24 \mathrm{~h}$ ) and white precipitate of magnesium alkoxide was formed. The suspension was cooled to ambient temperature and $\mathbf{1}(40 \mathrm{mg}, 0.073 \mathrm{mmol}), \mathbf{2}$ or $\mathbf{3}(0.734$ mmol) and dichlorobenzene $(4 \mathrm{ml})$ were added. The mixture was heated at $160{ }^{\circ} \mathrm{C}$ in argon atmosphere and monitored by MALDITOF MS until no changes in the spectra were observed ( $c a .48$ h). The reaction mixture was filtered through short pad of neutral alumina with $\mathrm{CHCl}_{3}$ as eluent and evaporated to dryness. The residue was applied to silica column. $4 \mathrm{Mg}$ was eluted with $\mathrm{CHCl}_{3}$ $\mathrm{MeOH}$ mixture $(0 \rightarrow 5$ vol. $\% \mathrm{MeOH})$, containing 0.5 vol. $\%$ of $\mathrm{Et}_{3} \mathrm{~N}$, yield $43 \% . \mathbf{5} \mathbf{M g}$ was eluted with acetone $/ \mathrm{CHCl}_{3}$ mixture (3/1 vol./ vol.), yield $26 \%$.

Synthesis of $4 \mathrm{Mg}$ with application of $\mathrm{Mg}(\mathrm{OAc})_{2}$. The mixture of 1 (40 mg, $0.073 \mathrm{mmol}), 2$ (200 mg, $0.734 \mathrm{mmol}), \mathrm{Mg}(\mathrm{OAc})$, $(125 \mathrm{mg}, 0.881 \mathrm{mmol})$ and DBU $(134 \mathrm{mg}, 0.881 \mathrm{mmol})$ in $i$-amyl alcohol $(4 \mathrm{ml})$ and chloro- or dichlorobenzene $(4 \mathrm{ml})$ was refluxed in argon atmosphere and monitored by MALDI-TOF MS until no changes in the mass-spectra were observed ( $c a .48$ (DCB) or $72(\mathrm{PhCl})$ hours). Afterwards the mixture was cooled to ambient temperature and evaporated to dryness. The residue was applied to silica column and eluted with $\mathrm{CHCl}_{3} / \mathrm{MeOH}$ mixtures $(0 \rightarrow 5$ vol.\% $\mathrm{MeOH})$, containing 0.5 vol. $\%$ of $\mathrm{Et}_{3} \mathrm{~N}$. Yield $39 \%$.

4Mg. MALDI-TOF MS: $\mathrm{m} / z$ calcd. for $\mathrm{C}_{124} \mathrm{H}_{148} \mathrm{Mg}_{2} \mathrm{~N}_{16} \mathrm{O}_{20}$ 2231.2, found 2231.4. UV-Vis $\left(\mathrm{CHCl}_{3}\right) \lambda \mathrm{nm}$ (rel. int.): 293 (0.395), 361 (0.654), 616 (0.208), 679 (1.000).

5Mg. MALDI-TOF MS: $m / z$ calcd. for $\mathrm{C}_{124} \mathrm{H}_{148} \mathrm{Mg}_{2} \mathrm{~N}_{16} \mathrm{O}_{32}$ 2423.2, found 2423.0. UV-Vis $\left(\mathrm{CHCl}_{3}\right) \lambda \mathrm{nm}$ (rel. int.): $292(0.547)$, 361 (0.942), 679 (1.000).

Demetallation of $\mathbf{4 M g}$ and $\mathbf{5 M g}$ with $\mathrm{AcOH}$. The starting compound $\mathbf{4 M g}(70 \mathrm{mg})$ or $\mathbf{5} \mathbf{M g}(46 \mathrm{mg})$ was dissolved in $\mathrm{CHCl}_{3}$ $(5 \mathrm{ml})$ and $\mathrm{AcOH}(5 \mathrm{ml})$ was added. The solution was refluxed and monitored by UV-Vis spectroscopy until no changes were observed in the spectra ( $c a .6$ hours). The resulting solution was evaporated to dryness, dissolved in $\mathrm{CHCl}_{3}$, passed through a pad of silica and further eluted from silica with $\mathrm{CHCl}_{3} / \mathrm{MeOH}(10-15$ vol.\% of $\mathrm{MeOH})$. Yield $86 \%\left(\mathbf{4} \mathbf{H}_{2}\right), 82 \%\left(\mathbf{5} \mathbf{H}_{2}\right)$.

Demetallation of $4 \mathrm{Mg}$ with application of $\mathrm{CF}_{3} \mathrm{COOH}$. The starting compound $\mathbf{4 M g}(133 \mathrm{mg})$ was dissolved in $\mathrm{CHCl}_{3}(20 \mathrm{ml})$ and $\mathrm{CF}_{3} \mathrm{COOH}(1 \mathrm{ml})$ was added. The solution was refluxed and monitored by UV-Vis spectroscopy until no changes were observed in the spectra ( $c a .2$ hours). The resulting solution was evaporated to dryness, dissolved in $\mathrm{CHCl}_{3}$, passed through a pad of silica and further eluted from silica with $\mathrm{CHCl}_{3} / \mathrm{MeOH}$ (10-15 vol.\% of $\mathrm{MeOH})$. Yield $88 \%$.

$4 \boldsymbol{H}_{2}$. MALDI-TOF MS: $m / z$ calcd. for $\mathrm{C}_{124} \mathrm{H}_{152} \mathrm{~N}_{16} \mathrm{O}_{20}$ 2186.6, found 2186.1. UV-Vis $\left(\mathrm{CHCl}_{3}\right) \lambda \mathrm{nm}$ (rel. int.): 296 (0.682), 349 (0.743), 409 (0.270), 429 (0.289), 605 (0.248), 646 (0.430), 665 (0.888), $703(1.000)$

$5 \boldsymbol{H}_{2}$. MALDI-TOF MS: $m / z$ calcd. for $\mathrm{C}_{124} \mathrm{H}_{152} \mathrm{~N}_{16} \mathrm{O}_{32}$ 2378.6, found 2378.8. UV-Vis $\left(\mathrm{CHCl}_{3}\right) \lambda \mathrm{nm}$ (rel. int.): 294 (0.883), 341 (1.000), 403 (0.428), 633 (0.728), 663 (0.695), 699 (0.485)

Template synthesis of $4 \mathrm{Ni}$. Mixture of $1(40 \mathrm{mg}, 0.073 \mathrm{mmol})$, 2 (200 mg, $0.734 \mathrm{mmol}), \mathrm{Ni}(\mathrm{OAc})_{2}(154 \mathrm{mg}, 0.881 \mathrm{mmol})$ and DBU (134 mg, $0.881 \mathrm{mmol}$ ) in $i$-amyl alcohol (4 ml) and dichlorobenzene $(4 \mathrm{ml})$ was refluxed in argon atmosphere and monitored by MALDITOF MS for 48 hours. The mixture was evaporated to dryness and the residue was applied to silica column. $\mathrm{CHCl}_{3} /$ hexane $(50 \rightarrow 100$ vol. $\%$ of $\left.\mathrm{CHCl}_{3}\right)$, and $\mathrm{CHCl}_{3} / \mathrm{MeOH}$ mixtures $(0 \rightarrow 15$ vol.\% of $\mathrm{MeOH})$ were subsequently used as eluents. The obtained $\mathbf{4 N i}$ was additionally purified by size exclusion chromatography with $\mathrm{CHCl}_{3} /$ $\mathrm{MeOH}$ (2.5 vol. $\%$ of $\mathrm{MeOH}$ ). Yield $22 \%$.

Synthesis of $\mathbf{4 N i}$ from $\mathbf{4} \mathbf{H}_{2}$. Mixture of $\mathbf{4} \mathbf{H}_{\mathbf{2}}(32 \mathrm{mg}, 0.015$ $\mathrm{mmol})$ and $\mathrm{Ni}(\mathrm{OAc})_{2}(42 \mathrm{mg}, 0.24 \mathrm{mmol})$ in dry DMF $(5 \mathrm{ml})$ was heated in argon atmosphere for 1.5 hours at $135^{\circ} \mathrm{C}$. The reaction pathway was monitored by UV-Vis spectra. The reaction mixture was poured in water $(100 \mathrm{ml})$ and kept at $5{ }^{\circ} \mathrm{C}$ for 1 hour. The formed precipitate was filtered, washed successively with water and dried. The obtained product was dissolved in $\mathrm{CHCl}_{3}$, passed through a pad of silica and further eluted from silica with $\mathrm{CHCl}_{3} / \mathrm{MeOH}$ (10-15 vol.\% of $\mathrm{MeOH}$ ). Yield $72 \%$. MALDITOF MS: $m / z$ calcd. for $\mathrm{C}_{124} \mathrm{H}_{148} \mathrm{~N}_{16} \mathrm{O}_{20} \mathrm{Ni}_{20} 2300.0$, found 2300.2 . UV-Vis $\left(\mathrm{CHCl}_{3}\right) \lambda \mathrm{nm}$ (rel. int): 290 (1.328), 410 (0.372), 620 (0.411), 645 (0.466), 673 (1.000)

\section{Results and Discussion}

The unsymmetrical phthalocyanines can be prepared as products of cross-condensation of phthalonitriles. In the case of the crown ether bridged phthalocyanine macrocycles, the key starting material is tetracyanodibenzo(24-crown-8) 1, which presents two sites for phthalocyanine ring formation. The starting substituted phthalonitriles were prepared according to described procedures (Scheme 1). [54,55] The tetranitrile $\mathbf{1}$ was prepared starting from dibenzo-(24-crown-8), which was brominated with NBS giving rise to corresponding tetrabromide. The obtained tetrabromodibenzo-(24-crown-8) was further involved in the palladium-promoted cyanation to produce the desired tetranitrile 1. Two dialkyloxyphthalonitriles were selected as counterparts in the cross-condensation, bearing peripheral butoxy- and 2-ethoxy-ethoxy-groups. These phthalonitriles 2 and $\mathbf{3}$ were synthesized from catechol in three-step procedure, which included alkylation, bromination of the corresponding dialkoxybenzene and either Rosenmund-Braun or Pdpromoted cyanation of the aromatic dibromides.

Typical conditions of phthalonitrile cross-condensation consist in interaction of components in stoichiometric ratio and further separation of the desired phthalocyanine from by-products with different ratio of phthalonitrile residues. This approach is reasonable in the case of mono-nucleus phthalocyanines, since the molar fraction of the desired phthalocyanine is maximal at the stoichiometric ratio of phthalonitriles in the case of statistical interaction of components with equal reactivity. ${ }^{[56,57]}$

In the case of the binuclear phthalocyanines under discussion, the $\mathrm{A}_{3} \mathrm{~B}$-type phthalocyanine, containing single residue of $\mathbf{1}$ is the semi-product of formation of the target dimeric phthalocyanines. The excess of the phthalonitrile 2 or 3 should be applied to suppress the formation of phthalocyanines of $\mathrm{A}_{2} \mathrm{~B}_{2}$ and other types on the first stage, since their further condensation leads to crown ether linked oligomers.

The phthalonitriles $\mathbf{1}$ and $\mathbf{2}$ in 1:10 molar ratio were involved in the condensation in isoamyl alcohol upon reflux in the presence of DBU for two days. Unfortunately, the formation of the desired dimeric phthalocyanine was determined only by MALDI-TOF MS in trace amounts. The reason for this result is extremely low solubility of the tetranitrile 1 in neat alcohol even upon reflux. The other observed problem was low overall conversion of phthalonitriles to phthalocyanines under applied conditions. These peculiarities require the additional solvent to be applied to solubilize 1 in the reaction media, while introduction of metal cations as templates may facilitate the conversion of nitriles to phthalocyanines. 


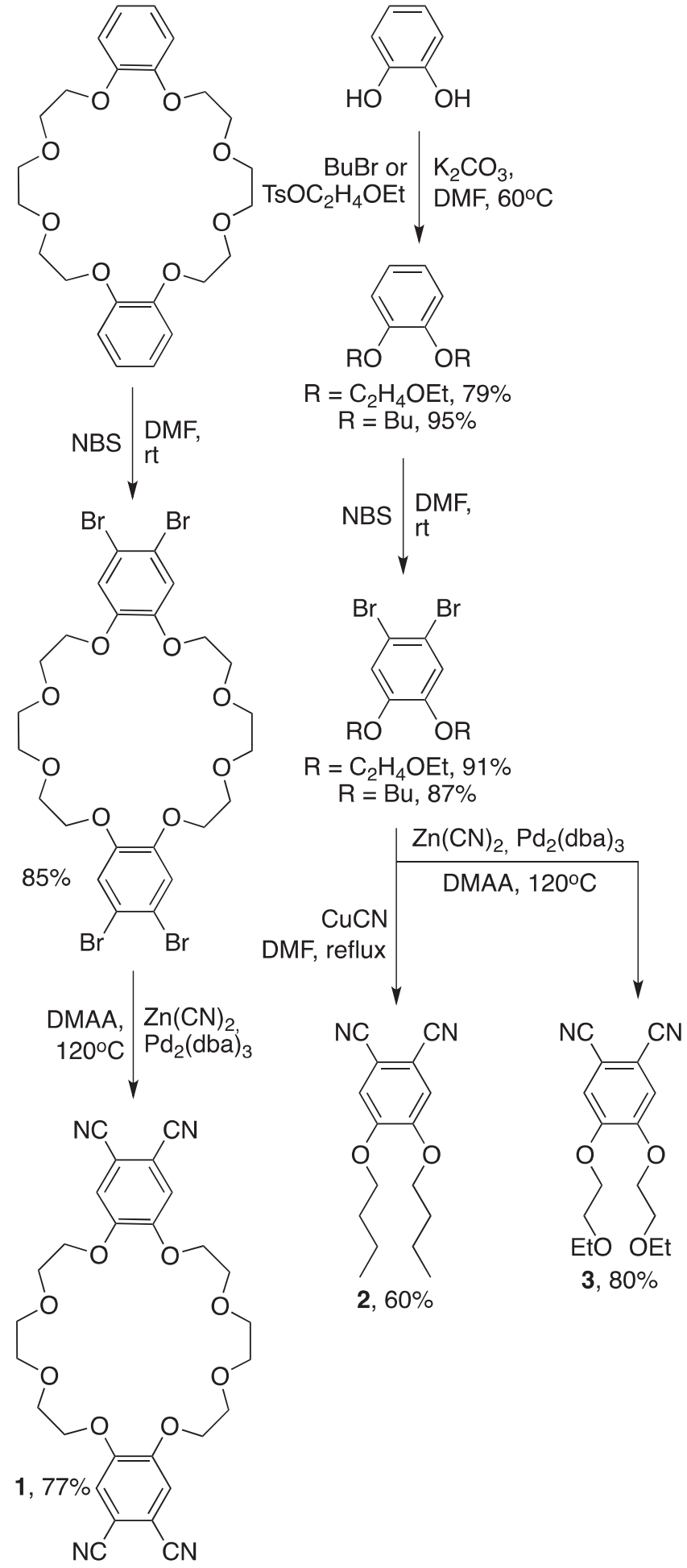

Scheme 1. Synthesis of starting phthalonitriles. ${ }^{[54,55]}$

The application of chloro- or 1,2-dichlorobenzenes as co-solvents allowed to achieve the solubility of $\mathbf{1}$ upon reflux of reaction mixture. Magnesium cation was chosen as template since it can be easily removed from the phthalocyanine producing metal-free ligand. The template cation can be introduced into the reaction mixture in two different ways: by application of magnesium alkoxide as nucleophile in the synthesis ${ }^{[58,59]}$ or by addition of magnesium salt ${ }^{[60,61]}$ to the reaction mixture. We have tested both approaches for preparation of the target dimeric phthalocyanines.
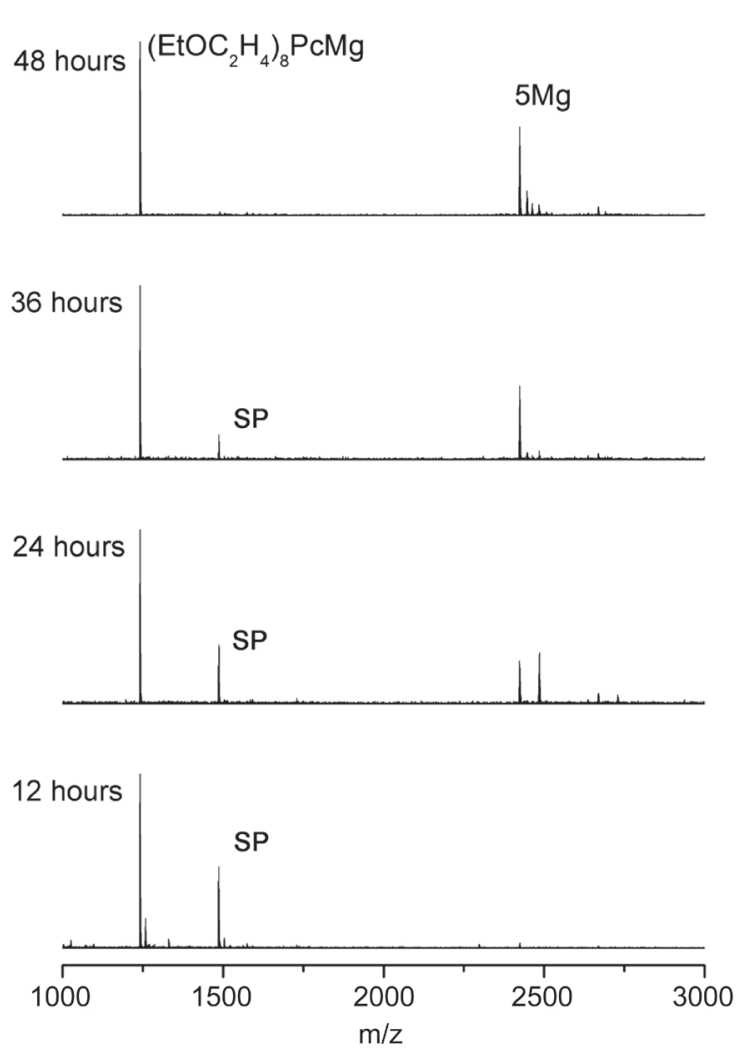

Figure 1. MALDI-TOF MS monitoring of the formation of $\mathbf{5 M g}$ with $\mathrm{Mg}\left(i-\mathrm{C}_{5} \mathrm{H}_{11} \mathrm{O}\right)_{2}$.

The main disadvantage of the application of magnesium alkoxide in the synthesis is the prolonged dissolution of magnesium filings in dry isoamyl alcohol, that takes up to 24 hours. The contrary approach, consisting in application of $\mathrm{Mg}(\mathrm{OAc})_{2}$ as template and DBU does not possess this disadvantage, while the chemical behavior of these systems is similar. The application of lithium alkoxyde as nucleophile in the condensation is disfavored in the presence of alkoxy-substituents, since their partial substitution under reaction conditions is reported. ${ }^{[62]}$ The formation of the target compound occurs in two steps (Scheme 2). The mass-spectral monitoring of the reaction path allowed to observe both steps, i.e. the formation of mononucleus phthalocyanine semi-product (SP) and its further conversion to the target dimeric phthalocyanine, as well as formation of traces of phthalocyanine oligomers (Figure 1). At the first stage of the reaction, e.g. ca. 12 hours of interaction, the peaks of magnesium octa-substituted phthalocyanine, SP and traces of the target dimeric magnesium phthalocyanine are observed in the mass spectra. Further interaction results in gradual decrease of the relative intensity of the semi-product peak. The reaction was continued until the SP peak in the mass-spectrum of the reaction mixture disappeared, testifying the complete conversion of the semi-product. Two main side-processes should be mentioned for this reaction - the formation of symmetrical side-product $(\mathrm{RO})_{8} \mathrm{PcMg}$ on the first step and the solvolysis of the phthalonitrile moiety of the (24-crown-8) substituted phthalocyanine on the second step.

It was found, that the yield of the reaction is virtually independent from $\mathrm{Mg}$-cation source and $\mathrm{Mg}(\mathrm{OAc})_{2} / \mathrm{DBU}$ 


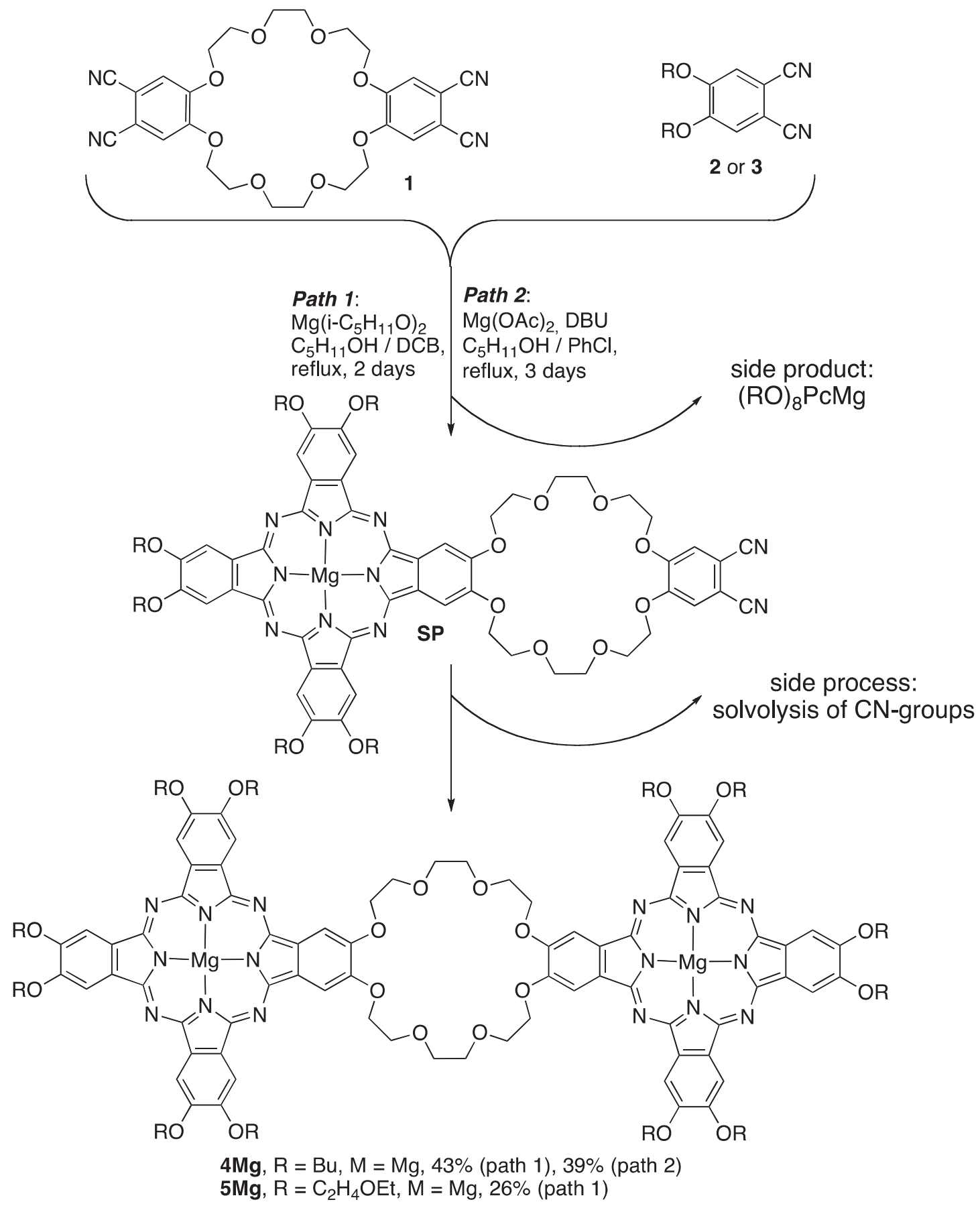

Scheme 2. Synthesis of dimeric Mg-phthalocyanines.

system can be used instead of magnesium alkoxide with slight decrease of yield. In contrast, the origin of peripheral substituents significantly alters the yield of the target dimeric phthalocyanine and $\mathbf{5} \mathbf{M g}$ is formed with lower yield, compared to $\mathbf{4 M g}$. The decrease of yields can be attributed to aggregation of (2-ethoxyethoxy) substituted phthalocyanine, compared to butoxy substituted analogy, resulting in its precipitation and further destruction under reaction conditions. Nevertheless, the obtained yields for 4Mg (39-43\%) and $\mathbf{5 M g}(26 \%) 2-4$ times exceed the published yields of related compounds. ${ }^{[1,53]}$ Other reaction media were tested in the synthesis in search for phthalonitriles solubility and increase of yields of products. We applied dimethylaminoethanol, morpholine, DMF and DMAA as co-solvents with $i$-amyl alcohol in $\operatorname{Mg}(\mathrm{OAc})_{2}$-templated condensation of dibuthoxyphthalonitrile as model reaction. Unfortunately, in all cases only traces of Mg-phthalocyanine were detected.

The chromatographic separation of the mixture of products at silica allowed to obtain dimeric Mg-phthalocyanines $\mathbf{4 M g}$ and $\mathbf{5 M g}$ as pure compounds. It should be mentioned that chromatographic mobility of $4 \mathbf{M g}$ and $(\mathrm{BuO})_{8} \mathrm{PcMg}$ is similar and partial coelution is observed, requiring repeated chromatographic separation. In the case of $\mathbf{5 M g}$ and the corresponding symmetrical phthalocyanine the difference in mobility is sufficient for complete separation. The crown-linked phthalocyanine oligomers are efficiently retained at silica and can not be eluted. 


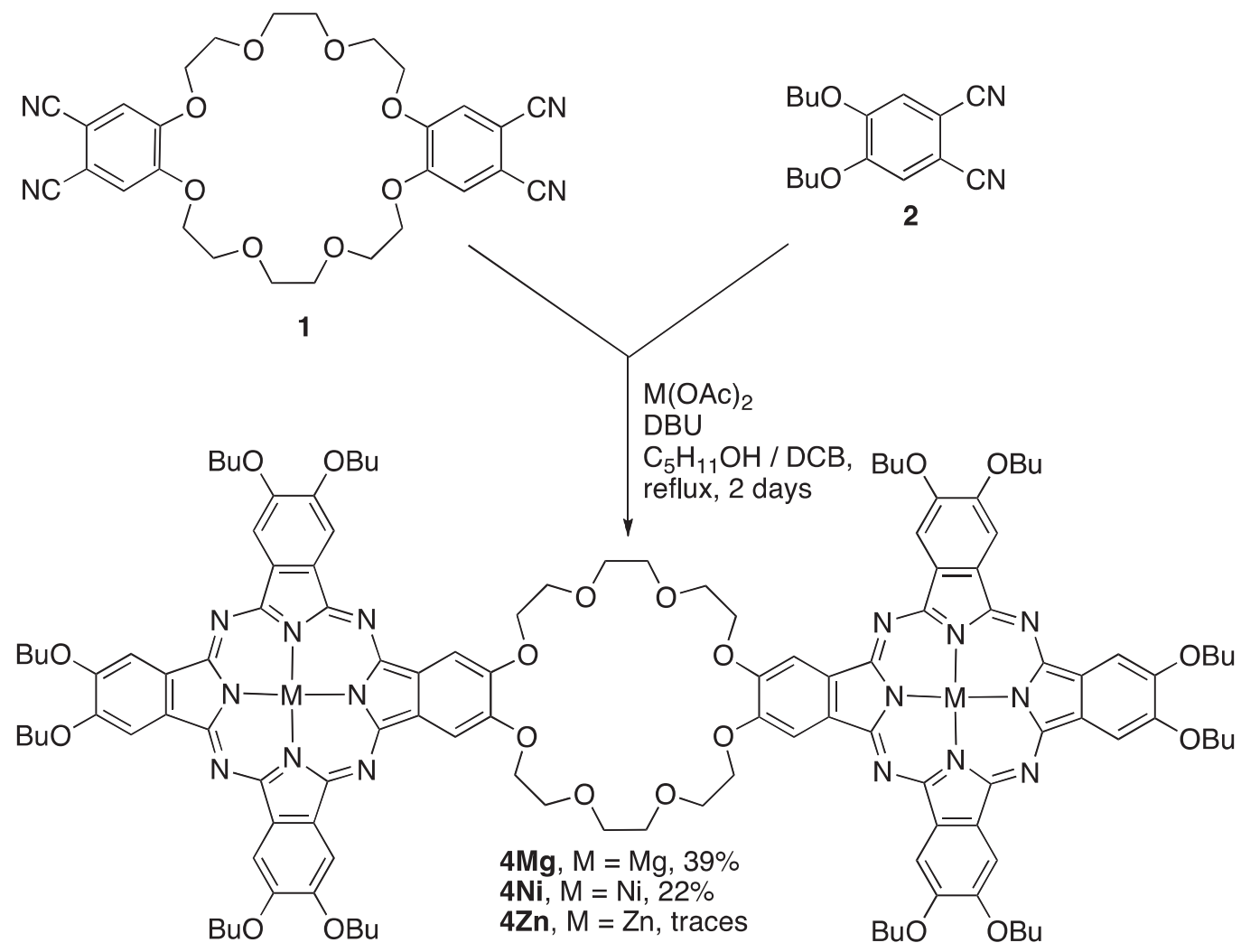

Scheme 3. Synthesis of metal complexes of (24-crown-8)-linked dimeric phthalocyanine.

With the determined optimal synthetic conditions the influence of the template metal cation onto the yields of the obtained complexes was investigated (Scheme 3). We attempted to prepare $\mathrm{Zn}$ and Ni complexes of butoxysubstituted dimeric phthalocyanine, namely $4 \mathbf{Z n}$ and $\mathbf{4 N i}$. The yield of Ni complex was decreased twice, compared to $\mathrm{Mg}$ complex, while $\mathrm{Zn}$ complex was determined only in trace amounts under these conditions. This peculiarity testifies $\mathrm{Mg}$ to be better template in the synthesis. Moreover, the separation of $\mathbf{4 N i}$ from the monomeric phthalocyanine by-product, $(\mathrm{BuO})_{8} \mathrm{PcNi}$, was significantly complicated by their co-elution at silica. Surprisingly, the application of size exclusion chromatography was inefficient for their separation, revealing the similar molecular size of these complexes in solution. The similarity of the molecular size and shape can be achieved in the case of closed cofacial conformation of dimeric phthalocyanine, which can be expected to be favorable in solution because of stabilization by intramolecular $\pi$ - $\pi$-stacking interaction. The possible explanation for specific behavior of $\mathrm{Mg}$ as a template in this reaction may

$4 \mathrm{Mg}$ or $5 \mathrm{Mg}$

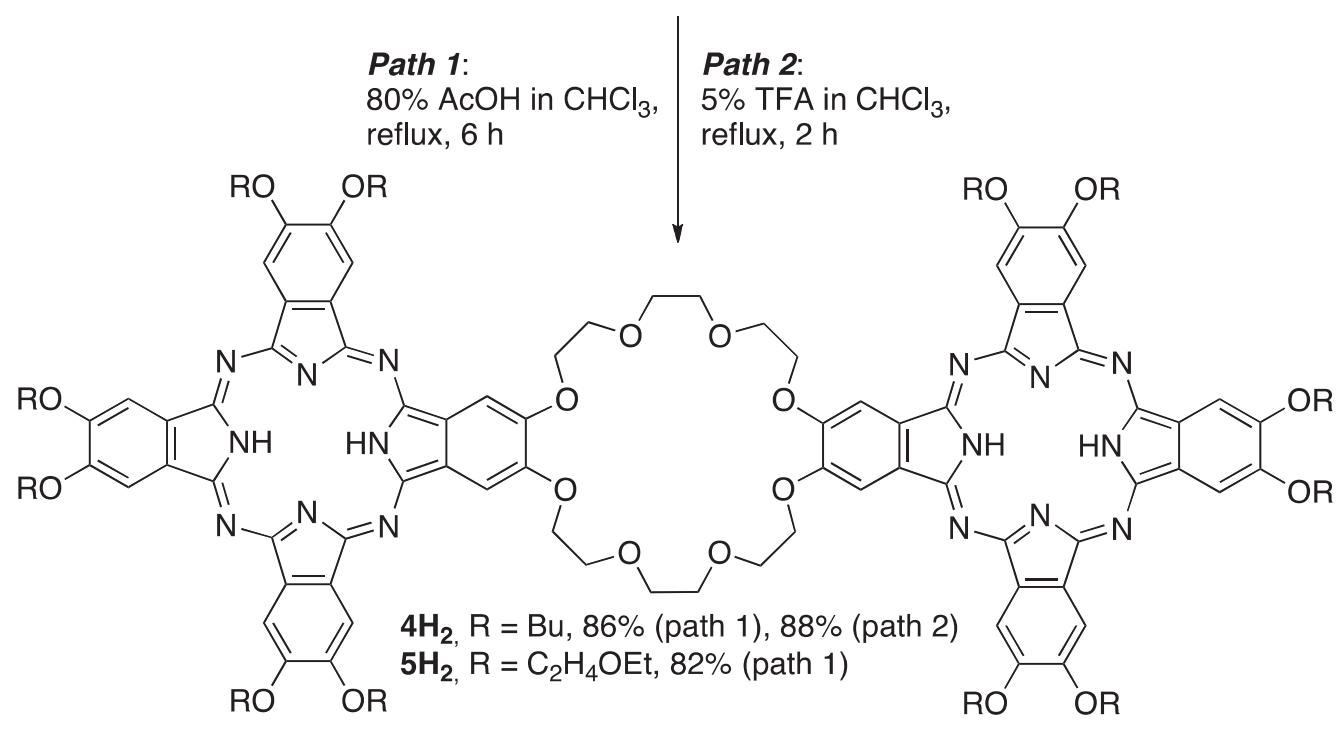

Scheme 4. Demetallation of Mg-phthalocyanines. 

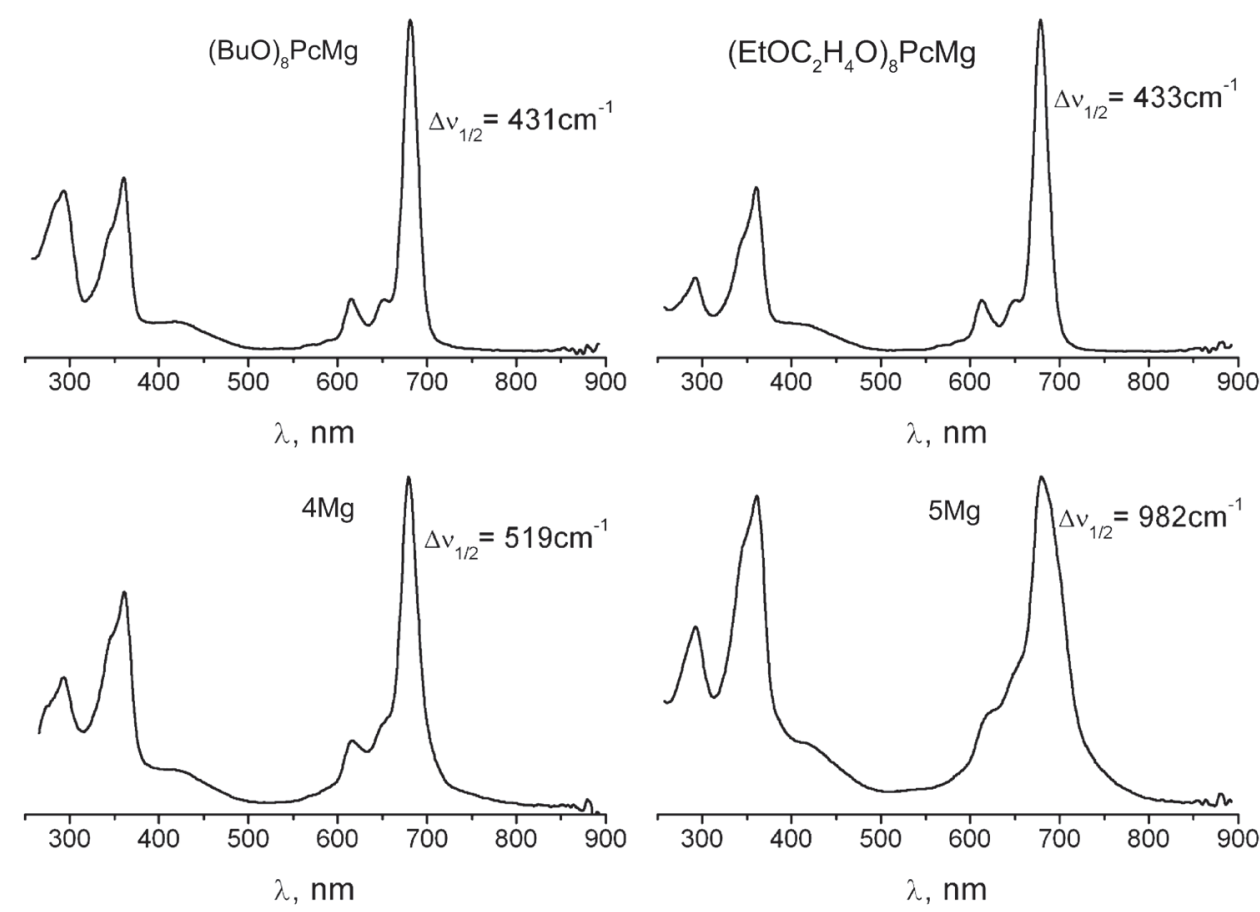

Figure 2. UV-Vis spectra of the obtained Mg-phthalocyanines in chloroform.
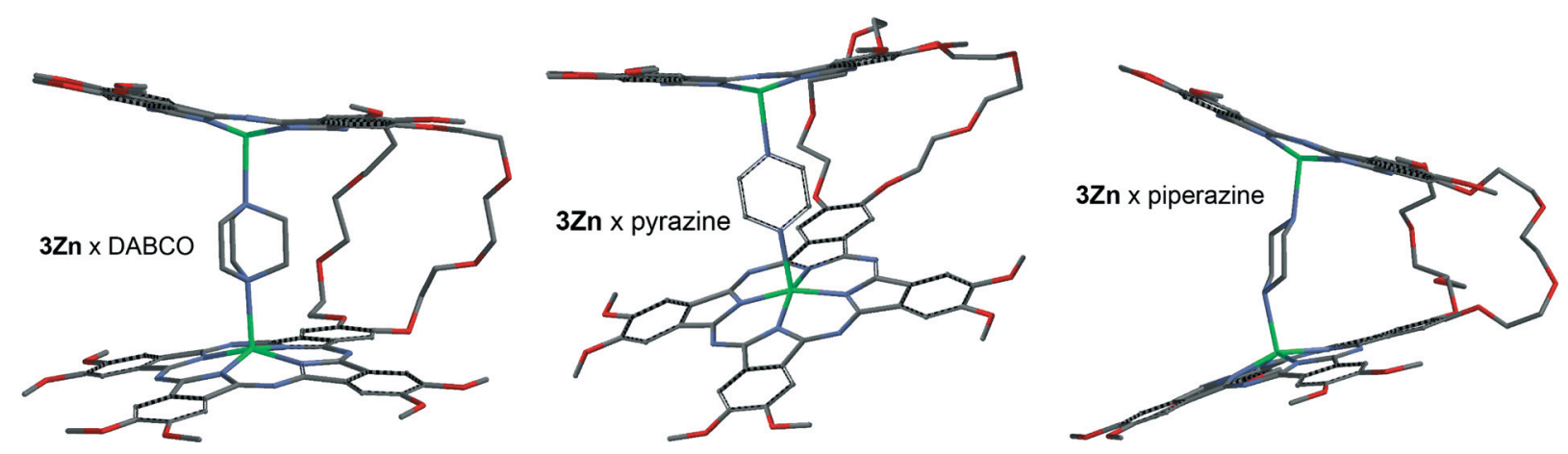

Figure 3. The calculated structures of association adducts of $\mathbf{3 Z n}$ with ditopic guests (AM1 method, protons are omitted for clarity).

consist in its covalent radius (1.41 $\AA)$, compared to $\mathrm{Zn}(1.22$ $\AA$ ) and $\mathrm{Ni}(1.24 \AA),{ }^{[63]}$ which can be the most appropriate for phthalonitrile molecules coordination in transition state and further tetramerization. It should be specially mentioned, that the choice of appropriate metal cation in this reaction results in 3-4 times increased yield of target compound, compared to previously reported ones. ${ }^{[13,53]}$

We have performed demetallation of the prepared $\mathrm{Mg}$ complexes under acidic conditions to prepare metal-free dimeric phthalocyanines (Scheme 4). A variety of methods for the demetallation of Mg-phthalocyanines is reported, ${ }^{[61,64,65]}$ which differ in origin of applied acid, from dissolution of the complex in concentrated sulphuric acid to reflux in acetic acid. We applied the mild conditions and performed the demetallation upon reflux either in $80 \%$ acetic acid or $5 \%$ trifluoroacetic acid in chloroform. Both approaches allowed complete demetallation of $\mathrm{Mg}$ complexes, differing only in reaction time. The complete conversion with acetic acid was achieved in 6 hours, while in the case of trifluoroacetic acid only two hours required for the reaction completion. The yields of metal-free complexes are found to be scarcely dependent from demetallation conditions and phthalocyanine peripheral substituents.

The preparation of metal complexes from metal-free crown-linked dimeric phthalocyanines was demonstrated with $\mathrm{Ni}$ as example. The treatment of metal-free ligand $\mathbf{4} \mathbf{H}_{2}$ with $\mathrm{Ni}(\mathrm{OAc})_{2}$ upon heating in DMF resulted in formation of $4 \mathrm{Ni}$ with $72 \%$ yield. It should be mentioned, that the obtained overall yield for the preparation of $\mathbf{4 N i}$ in 3 steps is even higher, than in the case of Ni-templated synthesis.

The obtained crown-linked dimeric phthalocyanines demonstrate high tendency to aggregation, compared to analogous octasubstituted monomeric phthalocyanines. It can be determined by UV-Vis spectra of the complexes in chloroform (Figure 2). The Q-bands of dimeric Mg-phthalocyanines $\mathbf{4 M g}$ and $\mathbf{5 M g}$ are broadened, compared to $(\mathrm{BuO})_{8} \mathrm{PcMg}$ and $\left(\mathrm{EtOC}_{2} \mathrm{H}_{4} \mathrm{O}\right)_{8} \mathrm{PcMg}$, respectively. Moreover, the half-width of Q-band of $5 \mathrm{Mg}$ twice exceeds that of $4 \mathrm{Mg}$. 
We have performed the preliminary semi-empirical AM1 calculations in order to analyze the receptor properties of the (24-crown-8)-linked dimeric phthalocyanine with $\mathrm{Zn}$ metal center as example (Figure 3 ). The calculations have shown that in the case of small ditopic molecules - DABCO, pyrazine or even piperazine, the axial coordination to the metal center of the receptor and thus pincer-type binding can be implemented without considerable distortion of the phthalocyanine macrocycle or crown ether fragment. It testifies, that the size of 24-crown-8 linking unit is sufficient for adaptation of the receptor to the guest molecule. The detailed investigation of binding properties of this type of receptors is to be published elsewhere.

\section{Conclusions}

The efficient approach for the preparation of dimeric phthalocyanines, linked by crown ether macrocycle, as well as corresponding metal complexes is developed. It is demonstrated, that application of $\mathrm{Mg}$ cation as template in the mixed condensation of phthalonitriles increases the yield of the phthalocyanine products of the reaction, compared to other cations and template-free synthesis. The obtained $\mathrm{Mg}$ complexes can be efficiently demetallated under mild acidic conditions affording metal-free phthalocyanines. In turn, metal-free dimeric phthalocyanines may further undergo complexation, thus making the developed approach general for the preparation of various metal complexes of dimeric crown ether linked phthalocyanines. The possible application of the prepared type of complexes for the development of pincer-type multicentered receptors is demonstrated by means of AM1 semi-empirical calculations.

Acknowledgements. This work was supported by Russian Foundation for Basic Research (grant 14-03-00977).

\section{References}

1. Katayev E.A., Ustynyuk Y.A., Sessler J.L. Coord. Chem. Rev. 2006, 250, 3004-3037.

2. Rebilly J.-N., Bistri O., Colasson B., Reinaud O. Inorg. Chem. 2012, 51, 5965-5974.

3. Sokkalingam P., Kee S.-Y., Kim Y., Kim S.-J., Lee P. H., Lee C.-H. Org. Lett. 2012, 14, 6234-6237.

4. Custelcean R. Chem. Soc. Rev. 2014, 43, 1813.

5. Koifman O.I., Mamardashvili N.Z., Antipin I.S., Synthetic Receptors Based on Porphyrins and Their Conjugates with Calix[4]arenes, Moscow: Nauka, 2006. 246 p. (in Russ.) [Койфман О.И., Мамардашвили Н.Ж., Антипин И.С. Синтетические рецепторы на основе порфиринов и их конъюгатов с каликс[4]аренами, М.: Наука, 2006. 246 с.]

6. Moerkerke S., Le Gac S., Topić F., Rissanen K., Jabin I. Eur. J. Org. Chem. 2013, 2013, 5315-5322.

7. Koifman O.I., Mamardashvili N.Z. Russ. Chem. Bull. 2013, 62, 123-132.

8. de la Torre G., Bottari G., Sekita M., Hausmann A., Guldi D.M., Torres T. Chem. Soc. Rev. 2013, 42, 8049-8105.

9. Makarov S.G., Suvorova O.N., Wöhrle D. J. Porphyrins Phthalocyanines 2011, 15, 791-808.

10. Tolbin A.Y., Tomilova L.G., Zefirov N.S. Russ. Chem. Rev. 2008, 77, 435-449.
11. Kumar A., Debnath A.K., Samanta S., Singh A., Prasad R., Veerender P., Singh S., Basu S., Aswal D.K., Gupta S.K. Sens. Actuators, B 2012, 171, 423-430.

12. Asano Y., Muranaka A., Fukasawa A., Hatano T., Uchiyama M., Kobayashi N. J. Am. Chem. Soc. 2007, 129, 4516-4517.

13. Guldi D.M., Ramey J., Martínez-Díaz M.V., de la Escosura A., Torres T., Da Ros T., Prato M. Chem. Commun. 2002, 27742775.

14. McKeown N. J. Mater. Chem. 2000, 10, 1979-1995.

15. Sorokin A.B. Chem. Rev. 2013, 113, 8152-8191.

16. Bala M., Verma P.K., Kumar N., Sharma U., Singh B. Can. J. Chem. 2013, 91, 732-737.

17. Bala M., Verma P.K., Sharma U., Kumar N., Singh B. Green Chem. 2013, 15, 1687-1693.

18. Zhang J., Li J., Ren T., Hu Y., Ge J., Zhao D. RSC Adv. 2014 , 4, 3206-3210.

19. Patir I.H. Electrochim. Acta 2013, 87, 788-793.

20. Zuo X., Li N., Zhang H. J. Mater. Sci. 2012, 47, 2731-2735.

21. Kılınç N., Öztürk S., Atilla D., Gürek A.G., Ahsen V., Öztürk Z.Z. Sens. Actuators, B 2012, 173, 203-210.

22. Abbas M.N., Radwan A.L.A., Bühlmann P., Ghaffar E., Abd M.A. Am. J. Anal. Chem. 2011, 2, 820-831.

23. El-Nemma E., Abd-Rabboh H., Hassan S. Int. J. Environ. Anal. Chem. 2010, 90, 148-158.

24. Açıkbaş Y., Evyapan M., Ceyhan T., Çapan R., Bekaroğlu Ö., Sens. Actuators, B 2009, 135, 426-429.

25. Andryushkevich S.O., Birin K.P., Gorbunova Y.G., Tsivadze A.Y. Prot. Met. Phys. Chem. Surf. 2011, 47, 494-502.

26. Birin K.P., Gorbunova Y.G., Tsivadze A.Y. Prot. Met. Phys. Chem. Surf. 2011, 47, 417-423.

27. Birin K.P., Kamarova K.A., Gorbunova Y.G., Tsivadze A.Y. Prot. Met. Phys. Chem. Surf. 2013, 49, 173-180.

28. Martynov A.G., Gorbunova Y.G., Tsivadze A.Y. Prot. Met. Phys. Chem. Surf. 2011, 47, 465-470.

29. Apetrei C., Nieto M., Rodríguez-Méndez M.L., de Saja J.A. J. Porphyrins Phthalocyanines 2011, 15, 908-917.

30. Gorbunova Y.G., Rodríguez-Méndez M.L., Kalashnikova I., Tomilova L.G., De Saja J. Langmuir 2001, 17, 5004-5010.

31. Martynov A.G., Gorbunova Y.G. Inorg. Chim. Acta 2007, 360, 122-130.

32. Selector S.L., Arslanov V.V., Gorbunova Y.G., Raitman O.A., Sheinina L.S., Birin K.P., Tsivadze A.Y. J. Porphyrins Phthalocyanines 2008, 12, 1154-1162.

33. Martynov A.G., Gorbunova Y.G., Tsivadze A.Y. Inorg. Chim. Acta 2009, 362, 11-18.

34. Selektor S.L., Shokurov A.V., Arslanov V.V., Gorbunova Y.G., Birin K.P., Raitman O.A., Morote F., Cohen-Bouhacina T., Grauby-Heywang C., Tsivadze A.Y. J. Phys. Chem., C 2014, $118,4250-4258$.

35. Grishina A.D., Gorbunova Y.G., Zolotarevsky V.I., Pereshivko L.Y., Enakieva Y.Y., Krivenko T.V., Savelyev V.V., Vannikov A.V., Tsivadze A.Y. J. Porphyrins Phthalocyanines 2009, 13, 92-98.

36. Morisue M., Fukui H., Shimizu M., Inoshita K., Morisaki Y., Chujo Y. Tetrahedron Lett. 2014, 55, 271-274.

37. Aar E. Dyes Pigm. 1997, 35, 269-278.

38. González A., Vazquez P., Torres T. Tetrahedron Lett. 1999, 40, 3263-3266.

39. Jiménez A.J., Marcos M.L., Hausmann A., Rodríguez-Morgade M.S., Guldi D.M., Torres T. Chem. Eur. J. 2011, 17, 1413914146.

40. García-Frutos E.M., Fernández-Lázaro F., Maya E.M., Vazquez P., Torres T. J. Org. Chem. 2000, 65, 6841-6846.

41. Ceyhan T., Altindal A., Özkaya A., Erbil M., Bekaroğlu Ö. Polyhedron 2007, 26, 73-84.

42. Koca A., Ceyhan T., Erbil M., Özkaya A., Bekaroğlu Ö. Chem. Phys. 2007, 340, 283-292. 
43. Wang K., Qi D., Wang H., Cao W., Li W., Liu T., Duan C., Jiang J. Chem. Eur. J. 2013, 19, 11162-11166.

44. Tolbin A.Y., Pushkarev V.E., Tomilova L.G., Zefirov N.S. Macroheterocycles 2011, 3, 30-32.

45. Dubinina T.V., Ivanov A.V., Borisova N.E., Trashin S.A., Gurskiy S.I., Tomilova L.G., Zefirov N.S. Inorg. Chim. Acta 2010, 363, 1869-1878.

46. Gorbunova Y.G., Martynov A.G., Tsivadze A.Y. Crown Substituted Phthalocyanines: From Synthesis towards Materials. In: Handbook of Porphyrin Science (Kadish K.M., Smith K.M., Guilard R., Eds.), World Scientific Publishing, 2012, Vol. 24, pp. 271-388.

47. Gorbunova Y.G., Lapkina L.A., Tsivadze A.Y. J. Coord. Chem. 2003, 56, 1223-1232.

48. Özdemir M., Ağar E. Spectrosc Lett. 1991, 24, 741-748.

49. Ahsen V., Yilmazer E., Bekaroğlu Ö. Makromol. Chem. 1988, 189, 2533-2543.

50. Ahsen V., Yilmazer E., Bekaroğlu Ö., Gül A. Makromol. Chem., Rapid Commun. 1987, 8, 243-246.

51. Abdurrahmanoğlu S., Özkaya A.R., Bulut M., Bekaroğlu Ö. Dalton Trans. 2004, 4022-4029.

52. Yilmaz I., Burkut Koçak M. Polyhedron 2004, 23, 1279-1285.

53. Kobayashi N., Opallo M., Osa T. Heterocycles 1990, 30, 389-392.
54. Martynov A.G., Birin K.P., Gorbunova Y.G., Tsivadze A.Y. Macroheterocycles 2013, 6, 23-32.

55. Wöhrle D., Schmidt V. J. Chem. Soc., Dalton Trans. 1988, 549-551.

56. Kopecky K., Šatinský D., Novakova V., Miletin M., Svoboda A., Zimcik P. Dyes Pigm. 2011, 91, 112-119.

57. Martynov A.G., Panova M.V., Gorbunova Y.G., Tsivadze A.Y. Macroheterocycles 2014, 7, 47-54.

58. Linstead R.P., Whalley M. J. Chem. Soc. 1952, 4839-4846.

59. Kobayashi N., Muranaka A., Nemykin V. Tetrahedron Lett. 2001, 42, 913-915.

60. Youssef T.E. Polyhedron 2010, 29, 1776-1783.

61. Kulinich V.P., Lebedeva T.A., Borisov A.V., Gorelov V.N., Shaposhnikov G.P. Russ. J. Gen. Chem. 2009, 79, 1728-1734.

62. Bai Z., Gao Y., Zhu P., Jaworski J., Jiang J. Inorg. Chem. 2010 , 49, 9005-9011.

63. Cordero B., Gómez V., Platero-Prats A.E., Revés M., Echeverría J., Cremades E., Barragán F., Alvarez S. Dalton Trans. 2008, 2832-2838.

64. Pushkarev V.E., Tolbin A.Y., Borisova N.E., Trashin S.A., Tomilova L.G. Eur. J. Inorg. Chem. 2010, 2010, 5254-5262.

65. Novakova V., Kopecky K., Miletin M., Ivincova J., Zimcik P. J. Porphyrins Phthalocyanines 2011, 15, 1062-1069. 